\title{
Analisis Niat Konsumen Menggunakan M Payment
}

\author{
Aglis Andhita Hatmawan \\ Fakultas Ekonomi dan Bisnis, Universitas PGRI Madiun \\ email: namaku.aglis @gmail.com
}

\begin{abstract}
Abstrak
Penelitian ini bertujan untuk melakukan analisis pengaruh persepsi kemudahan dan referensi kelompok dalam niat menggunakan $M$ payment dengan gender sebagai variabel moderasi. Data dianalisis menggunakan Structural Equation Modeling (SEM) pada 186 responden. Temuan dalam penelitian ini adalah bahwa niat menggunakan $M$ paymen di pengaruhi oleh persepsi kemudahan dan referensi kelompok. Hasil penelitian ini juga mengidentifikasi dua model yang berbeda dalam penggunaan M payment. Yang mana pria lebih ddidominasi oleh kemudahan didalam penggunaan layanan dibandingkan wanita, sedangkan pada wanita didominasi oleh referensi kelompok dalam penggunaan M payment
\end{abstract}

Kata Kunci : Mobile Payment, Gender, TAM

\section{A. PENDAHULUAN}

Sistem pembayaran telah berkembang dari yang semula hanya menggunakan transaksi tunai atau menggunakan kartu debet dan kredit kini telah meluas dengan sistem pembayaran yang baru yaitu melalui smartphone (Luna, 2018). Hal ini dikarenakan berkembangnya teknologi nirkabel khususnya internet dan perangkat seluler. Saat ini seluler telah bergesar dari yang sebelumnya hanya digunakan sebagai alat komunikasi sekarang berkembang menjadi sebuah alat yang serbaguna dan menjadi kebutuhan untuk semua orang. Hal ini juga berkembang pada sistem pembayaran itu sendiri, dimana sistem pembayaran menggunakan M-Payment konsumen atau masyarakat diuntungkan dengan berbagai promo yang diberikan terhadap penyedia layanan, kemudahan dan kenyamanan didalam bertransaksi dengan berbagai entitas yang ada.

Pertumbuhan industri $M$ payment berkembang secara signifikan (Nielsen, 2016). Hal ini ditandai dengan terus meningkatnya volume transaksi keuangan yang menggunakan $M$ payment, namun pertumbuhan Industri $M$ payment ini masih dibayangi oleh berbagai halangan diantaranya adalah pengetahuan konsumen itu sendiri terhadap sistem pembayaran menggunakan $M$ Payment (Francisco Liébana-Cabanillas, Muñoz-Leiva, \& Sánchez-Fernández, 2015), sistem keamanan dari $M$ Payment itu sendiri (Hwang, 2010). 
Terlepas dari hambatan tersebut bermunculan berbagai layanan $M$ Payment seperti Apple Pay, Samsung Pay, PayPal, Doku, Kartuku, Midtrans, Kesles, OVO, Go Pay dan masih banyak lagi. Menurut firma riset pasar TrendForce (Hsieh, 2016), skala pasar pembayaran mobile global akan mencapai US \$ 780 miliar pada akhir 2017, dengan peningkatan tahunan sebesar 25,8\%. Hal ini menunjukkan adanya sebuah tren dimana masyarakat saat ini mulai mengurangi penggunaan sistem pembayaran tunai dan sedikit demi sedikit beralih pada sistem pembayaran digital. Dengan berbagai macam aplikasi - aplikasi pembayaran yang semakin banyak tentu akan mengarah pada pertumbuhan $M$ Payment secara lebih lanjut kedepannya (Juniarti, 2018).

Indonesia dengan penduduk 264 juta jiwa merupakan potensi untuk berkembangnya sistem elektronik money ini namun hasil studi yang dilakukan oleh Global Financial Inclusion Index (2015) menunjukkan bahwa penduduk yang memiliki tabungan di bank hanya sebesar 36.1 persen dan hanya 2.9 persen yang mengunakan $M$ paymen, tentunya hal ini sangat kecil bila dibandingkan dengan jumlah penduduk yang ada di Indonesia. Hal senada juga diungkapkan dalam penelitian (Oliveira, Thomas, Baptista, \& Campos, 2016) yang menyebutkan bahwa masyarakat Indonesia yang menggunakan transaksi non tunai tidak lebih dari 1 persen.

Dengan berkembangnya trend $M$ Payment dan femonema diatas perlu dilakukan penelitian lebih lanjut tentang proses adopsi pemakaian M Payment dari sudut pandang konsumen dengan tiga konstruk penelitian yaitu kemudahan, preferensi grop, dan gender.

Disilain masih terbatasnya penelitian yang mengungkap tentang bagaimana perilaku masyarakat didalam memilih sebuah metode pembayaran baik tunai maupun $M$ Payment, dngan mengetahui perilaku masyarakat ini maka dimungkinkan untuk mengumpulkan sebuah informasi yang konferhensif dari sebuah sistem pembayaran mobile. Pengetahuan yang baru tersebut akan merangsang studi lebih lanjut mengenai teknologi yang berkaitan dengan alat - alat terkait guna meningkatkan efektifitas layanan yang disediakan bagi oleh penyedia. 
Kontribusi penelitian ini Pertama, penelitian ini mengungkap faktor penentu bagaimana masyarakat dalam memilih sistem pembayaran yang akan dipilih melalui sebuah model penelitian yang berlandaskan Teory Acceptance Model (TAM). Kedua, memproyeksikan serta memprediksi perilaku masyarakat pada sistem pembayaran non tunai yang telah banyak tersedia di pasaran dan melakukan evaluasi terhadap kemungkinan tehnologi baru terkait dengan hasil temuan penelitian ini.

\section{B. TINJAUAN PUSTAKA}

Banyak teori yang digunakan untuk menjelaskan sebuah perilaku seseorang didalam adopsi sebuah teknologi, diantaranya adalah teori yang dikembangkan oleh (Davis, 1993)) yaitu Tehology Acceptance Model (TAM) dan dikembangkan serta dimodifikasi oleh (Nysveen, Pedersen, \& Thorbjørnsen, 2005) yang mana secara umum niat seseorang menerima, menggunakan atau tidak sebuah tehnologi dipengaruhi oleh sikap, kemudahan, dan kegunaan dari tehnologi tersebut (Davis, 1993). Model ini juga telah digunakan untuk menguji tentang tiket seluler (Mohd Suki \& Mohd Suki, 2017), mobile banking
(Mehrad \& Mohammadi, 2017), egovernment (Rana, Dwivedi, Williams, \& Weerakkody, 2014) dan pembayaran mobile (Leong, Hew, Tan, \& Ooi, 2013)(F. Liébana-Cabanillas \& LaraRubio, 2017).

Banyak penelitian yang membahas tentang faktor penentu masyarakat didalam mengadopsi tehnologi yang didasarkan pada Teknology Aceptance Model (TAM) yang dikembangkan dari (Davis, 1989), dalam hal ini adalah layanan $M$ Payment. Seperti halnya penelitian yang dilakukan oleh (Jaradat \& Al-Mashaqba, 2014) yang berusaha mengungkapkan faktor - faktor yang mempengaruhi niat seseorang, didalam menggunakan M Payment di Yordania, dengan menggunakan model TAM. Hasil penelitiannya menunjukkan bahwa perilaku penggunaan $M$ paymen, dipengaruhi secara signifikan oleh variabel kemudahan didalam penggunaan, norma subyektif, kegunaan dan kontrol dari eksternal. Hal senada juga diteliti oleh (Keramati, et al, 2012) yang menyatakan bahwa persepsi kemudahan, persepsi kegunaan, kepercayaan, biaya, kebiasaan pembayaran mempengaruhi seseorang didalam penggunaan M Payment 
Di India (Thakur \& Srivastava, 2014) juga melakukan sebuah analisis variabel resiko didalam niat menggunakan pembayaran $M$ payment, dengan menelaah struktur hubungan antar variabel pada kelompok masyarakat yang berbeda - beda. (Koenig, et al 2015) juga melakukan studi pengembangan TAM dengan tambahan variabel pengaruh sosial, pengetahuan dan resiko yang dihadapi, serta kemampuan dan kenyamanan yang dirasakan terhadap penggunaan $M$ Payment. Hasil penelitiannya menunjukkan bahwa, tidak adanya pengaruh kemudahan didalam penggunaan $M$ payment, pada niat menggunakan alat pembayaran tersebut.

(Ramos. et al, 2017) yang meneliti faktor-faktor penerimaan konsumen terhadap sistem pembayaran mobile menggunakan teknologi NFC melalui model konseptual yang didasarkan pada TAM. Hasil mereka menunjukkan bahwa variabel seperti sikap, norma subyektif dan inovasi pribadi adalah penentu niat masa depan untuk melakukan pembayaran melalui teknologi NFC.

Salah satu variabel pada TAM adalah kemudahan didalam mengadopsi atau menggunakan tekhnologi tersebut, dalam hal ini kemudahan merupakan persepsi seseorang bahwa menggunakan sistem tertentu akan mudah dan cukup sederhana untuk diatasi (Taylor \& Todd, 1995) Sehingga hal tersebut dianggap merupakan aspek yang paling berpengaruh pada keputusan seseorang menggunakan tehnologi baru. Persepsi kemudahan penggunaan sebuah produk yang diarasakan seseorang telah dibuktikan pada banyak penelitian dngan konsteks yang berbeda (Schepers $\&$ Wetzels, 2007). Sehingga hipotesis dalam penelitian ini aadalah sebagai berikut:

$H 1$ : Terdapat pengaruh yang signifikan dari Persepsi kemudahan pada niat memilih M. Payment

Dalam penelitian - penelitian yang membahas tentang perilaku seseorang banyak dijumpai pengaruh dari sikap dan niat seseorang dalam berperilaku seseorang seperti halnya penelitian yang dilakukan oleh (Bagozzi \& Yi, 1988). Pengaruh dari referensi kelompok akan sangat mudah mendefinisikan tentang apa yang seseorang akan lakukan tentang sebuah perilaku tertentu dalam hal ini adalah menggunakan $M$ Payment. (Fishbein, M., \& Ajzen, 1975) 
didalam melakukan pengukuran pengaruh referensi kelompok ini menggunakan dua langkah yaitu pertama, kepercayaan normatif dan kedua adalah motivasi untuk mematuhi dari referensi yang berbeda. Norma subyektif merupakan pengaruh yang bersifat normatif seperti pengaruh yang berasal dari teman sebaya, orang tua dan saudara serta bersifat komparatif seperti contohnya adalah orang yang diidolakannya, pemimpin dan sebagainya (Chan \& Lu, 2011). Dalam penelitian ini referensi kelompok menggunakan pengaruh teman sebaya karena didalam pandangan peneliti teman sebaya lebih dominan didalam mempengaruhi seseorang berperilaku dibandingkan pengaruh dari orang tua, ataupun komunitas disekelilingnya (Schierz, Schilke, \& Wirtz, 2010). (Schierz et al., 2010) dalam penelitiannya terhadap 4.000 pengguna on line menunjukkan hasil bahwa sekitar $22 \%$ variasi niat seseorang dalam menerima iklan seluler. Hal senada juga diteliti oleh Heikki et al, (2008) hasil penelitiannya juga menunjukkan bahwa referensi kelompok mempengaruhi seseorang didalam menngunakan $M$ Marketing. Hipotesis dalam penelitian ini adalah
H2 : Terdapat pengaruh signifikan dari referensi kelompok pada niat menggunakan M Payment

Gender memilik peran moderasi (Meiranto, 2012). Laki - laki dan perempuan berbeda didalam cara bagaimana mereka memproses informasi dan lingkungan disekitarnya (Minahan \& Beverland, 2005). Sejumlah penelitian telah membuktikan bahwa laki - laki lebih obyektif, dan logis dibandingkan dengan perempuan. (Skitka et al., 1996) mengemukakan bahwa perempuan lebih menekankan pada harmonisasi fungsi dari kelompok terkait dan secara keseluruhan berfokus pada komunikasi didalam lingkup kelompoknya dalam mendeskripsikan orang lain serta lingkungannya. (Jayawardhena, 2008) menyebutkan bahwa perempuan lebih sering menggunakan layanan sms dibandingkan dengan laki - laki, salah satu alasannya yaitu perempuan lebih memandang dari sisi kesenangan serta dimensi sosial terkait dengan layanan seluler. Hipotesis dalam penelitian ini adalah

H3 : Hubungan antara kemudahan dan niat menggunakan $\mathrm{M}$ payment lebih 
kuat untuk laki - laki dibandingkan perempuan

H4 : Hubungan antara Referensi grop dengan niat menggunakan $\mathrm{M}$ payment lebih kuat perempuan dibandingkan laki - lak

\section{METODE PENELITIAN}

Desain penelitian ini menggunakan desain penelitian survei melalui pendekatan kuantatif dengan jenis penelitian adalah explanatory reseach. Populasi yang digunakan dalam penelitian ini adalah masyarakat Madiun. Tehnik pengambilan sampel menggunakan non probabiliti sampling, yaitu menggunakan metode Purposive sampling dengan kriteria responden telah menggunakan $M$ payment selama sekuragnya 1 tahun dari waktu penelitian ini dibuat. Pengumpulan data secara langsung kepada responden dengan menyebarkan kuesioner sebanyak 200 kuesioner, namun kuisioner yang bisa diolah sebanyak 186 kuesioner

Kuisioner dalam penelitian ini terdiri dari dua bagian, bagian pertama berisikan tentang identitas responden seperti, nama, alamat, gender, status pernikahan, pekerjaan dan umur. Bagian kedua berisikan daftar pertanyaan dari variabel dependen dan variabel independen yang terdiri dari persepsi kemudahan dan referensi group. Semua item pertanyaan mengukur persepsi subyektif dari responden yang diukur dengan skala $1 *$ sangat tidak setuju sampai dengan $5 *$ Sangat setuju.

Untuk melakukan uji validitas dan reliabilitas digunakan analisis Faktor dan tes chrombach alpha untuk menguji reliabilitas variabel sedangkan untuk melakukan uji hipotesis menggunakan SEM.

\section{HASIL DAN PEMBAHASAN}

Confirmatory Factor Analysis (CFA) digunakan untuk menilai validitas konstruk dalam penelitian ini, dengan 0,05 sebagai nilai referensi. Semua indikator didalam variabel telah diextrak secara sempurna dan mempunyai faktor loding $\geq 0,50$. Sedangkan untuk mengukur reliabilitas digunakan Alpha Cronbach, dengan 0,7 sebagai nilai referensi (Nunnally, 1978). Hasil dari pengujian menunjukkan semua variabel mempunyai nilai yang reliabel. 


\section{CA DTR AT JURNAL EKONOMI DAN MANAJEMEN \\ P-ISSN: 2598-9022/ E-ISSN: 2598-9618 \\ Available at: http://e-journal.unipma.ac.id/index.php/capital}

Setelah dilakukan skala pengukuran validitas dan reliabilitas pada masing masing variabel, langkah selanjutnya menguji kecukupan sampel data, normalitas data, asumsi outler dan analisis kesesuaian model, langkah selanjutnya diuji menggunakan metode statistik SEM.

Responden yang digunakan dalam penelitian ini berjumlah sebanyak 186 responden. Dengan jumlah responden tersebut telah memenuhi kriterian minimal sampel yang menngunakan prosedur Maximum Likehood Estimation dalam SEM. Langkah berikutya untuk memenuhi pengujian menggunakan SEM dilakukan uji normalitas data (Hair et al., 1998) Yaitu dengan mengetahui nilai critical rasio dari nilai skewness dan kurtosis sebaran data dimana nilai C.R harus lebih kecil dari nikai kritis yang dipersyaratkan. Hasil pengujian normalitas dalam penelitian ini termasuk moderately nonnormal, hal ini disebabkan hasi nilai rata - rata C.R nilanya menunjukkan $>2$ dan $<7$ untuk stiap item pertanyaan.

Hasil proses uji Goodess of fit dalam model penelitian ini bisa diterima seperti ditunjukkan pada Tabel I.
Tabel I. Goodness-of-Fit

\begin{tabular}{|l|l|l|}
\hline $\begin{array}{c}\text { Goodness of } \\
\text { Fit indeks }\end{array}$ & \multicolumn{1}{|c|}{$\begin{array}{c}\text { Nilai yang } \\
\text { Diharapkan }\end{array}$} & Hasil \\
\hline$x^{2}-$ Chi Square & & 640 \\
\hline Probabilitas & $\geq 0,05$ & 0.000 \\
\hline RMR & $<2 /<3$ & 1445 \\
\hline RMR & $<0,03$ & 0.036 \\
\hline GFI & $\geq 0.90$ & 0.882 \\
\hline AGFI & $\geq 0.90$ & 0.811 \\
\hline TLI & $\geq 0.90$ & 0.919 \\
\hline CFI & $\geq 0.90$ & 0.927 \\
\hline RMSEA & $\leq 0,08$ & 0.047 \\
\hline
\end{tabular}

Dari keseluruhan pengukuran goodness of fit tersebut $\mathrm{di}$ atas mengindikasikan bahwa model yang diajukan dalam penelitian ini dapat diterima. Setelah kriteria goodness of fit model struktural yang diestimasi dapat terpenuhi, selanjutnya analisis terhadap hubungan-hubungan struktural model (pengujian hipotesis) dapat dilakukan.

Hubungan antar konstruk dalam hipotesis ditunjukkan oleh nilai regression weights. Adapun hasil nilai regression weights di tunjukkan pada Tabel II. Berdasarkan hasil uji hipotesis pada Tabel II menunjukkan bahwa pesepsi kemudahan berpengaruh positif dan signifikan pada niat menggunakan $M$ payment pada laki - laki dan perempuan dengan nilai C.R sebesar 1.231 bagi laki laki dan 3.290 bagi perempuan, hal ini sejalan dengan penelitian yang dilakukan oleh (Ramos, 
et al, 2018) yang menyatakan bahwa perspsi kemudahan memengaruhi seseorang untuk menggunakan mobile payment.

Tabel II. SEM Hypothesis Testing.

\begin{tabular}{|c|c|c|c|c|c|}
\hline \multirow{2}{*}{$\begin{array}{l}\text { Hypothes } \\
\text { ized } \\
\text { parths }\end{array}$} & \multicolumn{5}{|c|}{ Laki -laki } \\
\hline & $\begin{array}{l}\text { Part } \\
\text { Coeffici } \\
\text { ents }\end{array}$ & $\begin{array}{l}\text { S. } \\
\text { E. }\end{array}$ & $\begin{array}{l}\text { C. } \\
\text { R. }\end{array}$ & $\rho$ & $\begin{array}{l}\text { suppor } \\
\text { ted }\end{array}$ \\
\hline $\mathrm{BI} \leftarrow \mathrm{PU}$ & .393 & $\begin{array}{l}.11 \\
0\end{array}$ & $\begin{array}{l}1.2 \\
31\end{array}$ & $\begin{array}{l}* * \\
*\end{array}$ & $\begin{array}{l}\text { H1 : } \\
\text { Yes }\end{array}$ \\
\hline \multirow[t]{3}{*}{$\begin{array}{l}\mathrm{BI} \\
\mathrm{RG} \\
\end{array}$} & .337 & $\begin{array}{l}.12 \\
7\end{array}$ & $\begin{array}{l}3.2 \\
46\end{array}$ & $\begin{array}{l}* * \\
*\end{array}$ & $\begin{array}{l}\mathrm{H} 2 \\
\text { Yes }\end{array}$ \\
\hline & \multicolumn{5}{|c|}{ Perempuan } \\
\hline & $\begin{array}{l}\text { Part } \\
\text { Coeffici } \\
\text { ents }\end{array}$ & $\begin{array}{l}\text { S. } \\
\text { E. }\end{array}$ & $\begin{array}{l}\text { C. } \\
\text { R. }\end{array}$ & $\rho$ & $\begin{array}{l}\text { suppor } \\
\text { ted }\end{array}$ \\
\hline $\mathrm{BI} \leftarrow \mathrm{PU}$ & .361 & $\begin{array}{l}.13 \\
5 \\
\end{array}$ & $\begin{array}{l}3.2 \\
90\end{array}$ & $\begin{array}{l}* * \\
*\end{array}$ & $\begin{array}{ll}\text { H1 : } \\
\text { Yes }\end{array}$ \\
\hline $\begin{array}{l}\mathrm{BI} \\
\mathrm{RG}\end{array}$ & .187 & $\begin{array}{l}.0 . \\
80\end{array}$ & $\begin{array}{l}2.1 \\
32\end{array}$ & $* *$ & $\begin{array}{l}\mathrm{H} 2: \\
\text { Yes }\end{array}$ \\
\hline \multicolumn{6}{|c|}{$* * \quad \rho$-Value $<0.1$} \\
\hline \multicolumn{6}{|c|}{$* * * \rho$-Value $<0.001$} \\
\hline
\end{tabular}

Hasil dari penelitian ini membuktikan bahwa rata - rata responden akan menggunakan $\mathrm{M}$ payment bila mereka merasa mudah dalam mempelajari dan mengunakan teknologi tersebut. Sehingga sistem yang dianggap lebih mudah digunakan akan memudahkan pengguna untuk menyelesaikan tugas yang lebih banyak dibandingkan sistem yang lebih sulit (Morris, 2012).

Referensi kelompok berpengaruh pada niat menngunakan $M$ payment baik pada laki- laki maupun perempuan dengan nilai C.R sebesar 3.246 bagi laki - laki dan 2.132 bagi perempuan, hal ini senada dengan hasil temuan dari (Jayawardhena, 2008) dengan meneliti 8.578 responden yang hasilnya menyatakan bahwa referensi kelompok mempengaruhi seseorang didalam niat menggunakan teknologi berbasis seluler. Dalam banyak literatur juga ditemui bahwa referensi kelompok sangat mempengaruhi niat dan perilaku konsumen (Bagozzi, 2000)

Tabel III. Comparing The Intensity Of Part Differences.

\begin{tabular}{|l|l|l|l|}
\hline & & $\begin{array}{l}\text { Evidence } \\
(\rho \text {-value })\end{array}$ & Kesimpulan \\
\hline $\mathrm{BI} \leftarrow \mathrm{PU}$ & $\mathrm{M}<\mathrm{F}$ & $*$ & H3 : Didukung \\
\hline $\mathrm{BI} \leftarrow \mathrm{RG}$ & $\mathrm{M}>\mathrm{F}$ & $*$ & H4 : Didukung \\
\hline $\mathrm{P}-$ Value $<.05$. & & & \\
\hline
\end{tabular}

Dari tabel III menunjukkan bahwa persepsi kemudahan lebih besar pria dibandingkan dengan wanita, sedangkan referensi kelompok lebih besar wanita bila dibandingkan pria. Hal ini sesuai dengan penelitian yang dilakukan oleh (Ramos et al., 2018) yang menyatakan bahwa laki - laki lebih bersifat maskulin sedangkan wanita lebih bersifat feminim sehingga dalam hal ini perempuan akan memiliki kecederungan untuk membanngun sebuah harmonisasi fungsi - fungsi kelompok dan keterkaitan didalam 


\section{CA DTR AT JURNAL EKONOMI DAN MANAJEMEN \\ P-ISSN: 2598-9022/ E-ISSN: 2598-9618 \\ Available at: http://e-journal.unipma.ac.id/index.php/capital}

kelompoknya. Sedangkan pada laki laki lebih pada rasionalitas dan kemudahan yang diperolehnya didalam menggunakan sebuah tekhnologi

\section{E. SIMPULAN}

Kesimpulan dalam penelitian ini adalah bahwa didalam memahami sebuah niat seseorang didalam menggunakan tekhnologi kita harus kembali menelusuri teori - teori yang telah ada, dalam upaya yntuk mengetahui hubungan antar konstruk dalam upaya untuk memahami penggunaan $M$ Payment. Dalam mengembangkan sebuah layanan $M$ payment sebaiknya penyedia layanan harus memperhatikan dari kemudahan dalam pengoperasian layanan tersebut baik fitur - fitur yang mudah dipahami oleh pengguna serta penting untuk menggunakan referensi kelompok didalam pengenalan dan pemasaran layanan $M$ payment karena dari hasil penelitian menunjukkan bahwa referensi kelompok berpengaruh pada niat konsumen dalam menggunakan $M$ payment.

\section{DAFTAR PUSTAKA}

Bagozzi, R. P. (2000). Consumer

Behavior. Journal Of Consumer
Research, 27(December 2000), 388-396.

Bagozzi, R. P., \& Yi, Y. (1988). On the evaluation of structural equation models. Journal of the Academy of Marketing Science, 16(1), 74-94. https://doi.org/10.1007/BF0272332 7

Chan, S., \& Lu, M. (2011). Understanding Internet Banking Adoption and Use Behavior. Advanced Topics in Global Information Management, Volume $5,12(3), 21-43$. https://doi.org/10.4018/978159140 9236.ch014.ch000

Davis, F. D. (1989). Perceived Usefulnees, Perceived Ease of Use, and User Acceptance of Information Technology. MIS

Quarterly, 13(3), 319-340. https://doi.org/10.1016/S03050483(98)00028-0

Davis, F. D. (1993). TAM Davis 1991.pdf. Int. J. Man-Machine Studies, 38, 475-487.

Fishbein, M., \& Ajzen, I. (1975). Belief, Attitude, Intention, and Behavior: An Introduction to Theory and Research. USA: Addison-Wesley. Heikki Karjaluoto, Heikki Lehto, M. L.

N. A. C. J. (2008). Exploring 
Gender Influence on Customer's

Intention to Engage Permission-

based Mobile Marketing.

Electronic Markets, Vol. 18 No, 242-259.

Hwang, Y. (2010). The moderating

effects of gender on e-commerce

systems adoption factors: An

empirical investigation. Computers

in Human Behavior, 26(6), 1753-

1760.

https://doi.org/10.1016/j.chb.2010.

07.002

Jaradat, M. I. R. M., \& Al-Mashaqba,

A. M. (2014). Understanding the

adoption and usage of mobile

payment services by using TAM3 .

International Journal of Business

Information Systems, 16(3), 271-

296.

https://doi.org/10.1504/IJBIS.2014

.063768

Jayawardhena, C. (2008). Exploring

Gender Influence on Customer ' $\mathrm{s}$

Intention to Engage Permission-

based Mobile Marketing.

Electronic Markets, 18(2), 242-

259.

Juniarti, R. P. (2018). Faktor-Faktor

Yang Memengaruhi Penggunaan

Mobile Payment : Sebuah Review

Literature. Sinergitas Quadruple
Helix: E-Business Dan Fintech

Sebagai Daya Dorong

Pertumbuhan Ekonomi Lokal,

526-534.

Keramati, A., Taeb, R., Larijani, A. M.,

\& Mojir, navid. (2012). A

combinative model of behavioural

and technical factors affecting

'Mobile'-payment services

adoption: An empirical study.

Service Industries Journal, 32(9),

1489-1504.

https://doi.org/10.1080/02642069.2

011.552716

Koenig-Lewis, N., Marquet, M.,

Palmer, A., \& Zhao, A. L. (2015).

Enjoyment and social influence:

predicting mobile payment

adoption. Service Industries

Journal, 35(10), 537-554.

https://doi.org/10.1080/02642069.2

015.1043278

Leong, L. Y., Hew, T. S., Tan, G. W.

H., \& Ooi, K. B. (2013). Predicting the determinants of the NFC-

enabled mobile credit card acceptance: A neural networks approach. Expert Systems with Applications, 40(14), 5604-5620. https://doi.org/10.1016/j.eswa.201 3.04 .018

Liébana-Cabanillas, F., \& Lara-Rubio, 
J. (2017). Predictive and

explanatory modeling regarding

adoption of mobile payment

systems. Technological

Forecasting and Social Change, 120(July 2016), 32-40.

https://doi.org/10.1016/j.techfore.2

017.04.002

Liébana-Cabanillas, Francisco, Muñoz-

Leiva, F., \& Sánchez-Fernández, J.

(2015). Behavioral Model of

Younger Users in M-Payment

Systems. Journal of

Organizational Computing and

Electronic Commerce, 25(2), 169190.

https://doi.org/10.1080/10919392.2

015.1033947

Luna, I. R. de. (2018). Mobile payment is not all the same: The adoption of mobile payment systems depending on the technology applied. Technological Forecasting \& Social Change, 40, 40-56.

Mehrad, D., \& Mohammadi, S. (2017). Word of Mouth impact on the adoption of mobile banking in Iran. Telematics and Informatics, 34(7), 1351-1363. https://doi.org/10.1016/j.tele.2016. 08.009
Meiranto, W. (2012). Analisis Faktor

Faktor Yang Mempengaruhi Minat

Pemanfaatan Dan Penggunaan

Teknologi Pembayaran Elektronik

Bergerak Dengan Menggunakan

Model Utaut. Jurnal Akuntansi

Indonesia, 1, 40-50.

Minahan, S., \& Beverland, M. B.

(2005). Why Women Shop : Secrets Revealed. Milton, QLD, Australia: John Wiley \& Sons Australia Ltd. Mohd Suki, N., \& Mohd Suki, N. (2017). Flight ticket booking app on mobile devices: Examining the determinants of individual intention to use. Journal of Air Transport Management, 62, 146154.

https://doi.org/10.1016/j.jairtraman .2017 .04 .003

Morris, M. G. (2012). Why Don 'T Men Ever Stop To Ask For Directions? Gender, Social Influence, And Their Role In Technology And Usage Behavior1. 24(1), 115-139.

Nielsen. (2016). Mobile money: from shopping to banking to payments, how mobile is transforming commerce around the world. Nysveen, H., Pedersen, P. E., \& Thorbjørnsen, H. (2005). Intentions to use mobile services: 
Antecedents and cross-service

comparisons. Journal of the

Academy of Marketing Science, 33(3), 330-346.

https://doi.org/10.1177/009207030 5276149

Oliveira, T., Thomas, M., Baptista, G., \& Campos, F. (2016). Mobile payment: Understanding the determinants of customer adoption and intention to recommend the technology. Computers in Human Behavior, 61(2016), 404-414. https://doi.org/10.1016/j.chb.2016. 03.030

Ramos-de-Luna, I., Montoro-Ríos, F., Liébana-Cabanillas, F., \& Luna, J. G. de. (2017). NFC technology acceptance for mobile payments: A Brazilian Perspective. Review of Business Management, 19(63), 82103.

https://doi.org/10.7819/rbgn.v0i0.2 315

Ramos, I., Luna, D., Liébana-cabanillas, F., Sánchez-fernández, J., \& Muñoz-leiva, F. (2018).

Technological Forecasting \& Social Change Mobile payment is not all the same : The adoption of mobile payment systems depending on the technology applied. Technological

Forecasting \& Social Change, (September), 1-14. https://doi.org/10.1016/j.techfore.2 018.09.018

Rana, N. P., Dwivedi, Y. K., Williams, M. D., \& Weerakkody, V. (2014). Investigating success of an egovernment initiative: Validation of an integrated IS success model. Information Systems Frontiers, 17(1), 127-142. https://doi.org/10.1007/s10796014-9504-7

Schepers, J., \& Wetzels, M. (2007). A meta-analysis of the technology acceptance model: Investigating subjective norm and moderation effects. Information and Management, 44(1), 90-103. https://doi.org/10.1016/j.im.2006.1 0.007

Schierz, P. G., Schilke, O., \& Wirtz, B. W. (2010). Understanding consumer acceptance of mobile payment services: An empirical analysis. Electronic Commerce Research and Applications, 9(3), 209-216. https://doi.org/10.1016/j.elerap.200 9.07.005

Skitka, L. J., Maslach, C., Heim, L., 
Carmody, C., Lee, C., \& Shen, R. (1996). Gender as schematic category: a role construct approach 1. Social Behavior And Personality, 24(1), 53-73.

https://doi.org/10.2224/sbp.1996.2

4.1 .53

Taylor, S., \& Todd, P. A. (1995). Understanding information technology usage: A test of competing models. Information Systems Research, 6(2), 144-176. https://doi.org/10.1287/isre.6.2.144

Thakur, R., \& Srivastava, M. (2014). Adoption readiness, personal innovativeness, perceived risk and usage intention across customer groups for mobile payment services in India. Internet Research, 24(3), 369-392. https://doi.org/10.1108/IntR-122012-0244 